\title{
Including the voices of communities in food insecurity research: An empowerment-based agenda for food scholarship
}

\author{
Adam M. Pine ${ }^{a} *$ and Rebecca de Souza ${ }^{b}$ \\ University of Minnesota Duluth
}

Submitted June 4, 2013 / Revised July 25, 2013 / Published online August 5, 2013

Citation: Pine, A. M., \& de Souza, R. (2013). Including the voices of communities in food insecurity research:

An empowerment-based agenda for food scholarship. Journal of Agriculture, Food Systems, and Community

Development, 3(4), 71-79. http://dx.doi.org/10.5304/jafscd.2013.034.007

Copyright (C) 2013 by New Leaf Associates, Inc.

\begin{abstract}
The disempowering manner in which "hungry people" are portrayed in public discourse and the dehumanizing way in which they are treated when they try to provision for themselves demand that scholars create counter frames to subvert the existing portrayal of those experiencing food insecurity. In this paper, we call for a program of research that uses participatory research methodologies to invite, recognize, and represent the voices of people experiencing food insecurity. We argue for an expanded program of food

a * Corresponding author: Adam M. Pine, Ph.D., University of Minnesota Duluth, 317 Cina Hall, 1123 University Drive, Duluth, Minnesota 55812 USA; +1-218-726-8474; apine@d.umn.edu

b Rebecca de Souza, Ph.D., University of Minnesota Duluth, 415 A. B. Anderson Hall, 1121 University Drive, Duluth, Minnesota 55812 USA; +1-218-726-6616; rdesouza@d.umn.edu
\end{abstract}

scholarship that places the experiences, needs, and voices of people experiencing food insecurity in the foreground. Such a program is needed in order to better understand the lived reality of food insecurity, how interventions can be designed for communities as partners in research rather than objects of investigation, and how communities can mobilize themselves for broader environmental change.

\section{Keywords}

community-based participatory research, food insecurity, marginalization

\section{Introduction}

The past decade has seen a wealth of studies from a variety of disciplinary and methodological perspectives investigating the complex problem of food insecurity in the United States. While useful, this body of work has overlooked the voices of 
people experiencing the daily burden of food insecurity by focusing on them as research subjects, rather than as participants or agents in a process of change. In this commentary, we argue for an expanded program of food scholarship that places the experiences, needs, and voices of people experiencing food insecurity in the foreground. To do so the research agenda of food scholars must be repositioned to focus squarely on forming partnerships with communities experiencing food insecurity and using their voices to guide activism. We call for a program of research that uses participatory research methodologies to invite, recognize, and represent the voices of people experiencing food insecurity. This is needed in order to better understand the lived reality of food insecurity, how interventions can be designed for communities as partners in research rather than objects of investigation, and how communities can mobilize themselves for broader environmental change. In short, we call for a program of scholarship that asks how can we create a more equitable way of knowing about our food system that includes the voices of people who are food insecure in the design and implementation of our research, as well as in advocacy to bring about change.

\section{The Discursive Erasure of People Living with Food Insecurity}

In popular discourse, the solution to the problem of hunger is usually framed as a question of charity (Poppendieck, 1999), instead of a fundamental question of citizenship and political empowerment. Within the existing structure, corporate and government actors are represented positively for their food donations, while food-insecure people are either absent or represented in a degrading manner via pitiable images of hungry people and children (DeLind, 1994; Retzinger, 2012). The disempowering manner in which "hungry people" are portrayed in public discourse and the dehumanizing way in which they are treated when they try to provision for themselves demand that scholars create counterframes to subvert the existing portrayal of those experiencing food insecurity. It is a matter of great urgency for researchers to represent for the voices of people living with food insecurity and to use research methodologies that include the values, meanings, and subjective experiences of people experiencing food insecurity. Because material disenfranchisement is intrinsically linked to communicative disenfranchisement, research must attend to the discursive marginalization of people who are food insecure as well as the broader context of power relations. In short, we argue for a program of research that weakens the power of dominant discourses and creates spaces for competing community discourses to emerge.

A particular instance of the silencing of foodinsecure people can be seen in the ubiquitous food drives to "fight," "end," or "stamp out" hunger. Donation is portrayed as a win-win situation where the giver benefits emotionally and spiritually by being charitable, and "the hungry" benefit by receiving their largesse. In the spectacle of food drives, the interests of corporations, government agencies, and food banks are represented, but who exactly is at the receiving end of this stock of "unsaleable" food items remains unclear. In DeLind's analysis of Michigan Harvest Gathering, a state-coordinated emergency food and antihunger campaign, she writes "the hungry were 'imaged out' of the very issue to which they were central" and "remained unknown, impersonal, and deficient" (DeLind, 1994, p. 62). In short, 15 percent of the population - in all its variability and uniquenessis characterized by the phrase "in need." This onedimensional frame allows for the wider public to morally engage with the issue of hunger, but at the same time remain disengaged from the people who experience it.

The silence of food-insecure people is further accomplished through an underlying assumption of personal responsibility that permeates the issue of food insecurity, while the role of the state is largely missing (Chilton \& Rose, 2009). In an increasingly neoliberal context, problems of ill health, unemployment, and homelessness are conceived of as individual problems caused by personal failure and deficiencies, rather than pervasive structural factors. Government nutrition assistance programs may be referred to as "entitlements," but insinuations about the inherent laziness, neediness, and unhealthy behaviors of this "class" of people abound, which in turn transforms talk about rights and entitlements into talk about abuse of taxpayer 
money; as a result, clients feel they cannot speak out against programs, organizers, or the food distributed because this would be seen as abuse of charitable good will (Tarasuk \& Eakin, 2005). Another consequence is that when people attempt to provision for themselves and their families by visiting food banks, soup kitchens, or other such emergency food sites, they must endure a range of indignities including stigma and discrimination (Poppendieck, 1999). When viewed through the lens of a rights-based approach, however, access to good food and nutrition is not about charity, but rather about the duty of the government to facilitate food access for its citizens (Anderson, 2008; Chilton \& Rose, 2009). This is even referred to as "entitlement failure" by international economists (Sen, 1983).

We believe that there is a connection between the commodification of food and the political disempowerment of those experiencing food insecurity. Food is laden with value and meaning; however, these meanings have been erased through the commodification of food, and doing so has silenced personal, social, and cultural subjectivities. The food-insecurity discourse reinforces the notion of food-insecure people as simply lacking a particular commodity. But food is about how we experience, express, and interpret cultural values. It is about sitting down to dinner with the family, packing snacks for a child to take to school, and sharing meals for celebration and grief. The discourse of numbers and the rhetoric of quantification used to talk about both food (e.g., number of items, poundage of food) and the food insecure (e.g., prevalence and percentages) reinforces a way of thinking that prioritizes financial and market values at the expense of human values and relationships. In this reductionist framework, the solution is to render food-insecure people into "clients" of the system, where they must accept poor quality food in limited quantity or engage in novel techniques to solve this problem of access to commodities.

\section{Moving Toward a Participatory Research Agenda}

Critical, feminist, and postcolonial theories provide useful lenses to deepen our understanding of the importance of community participation in the production of knowledge. These theoretical orientations confront us with the idea that knowledge is socially and historically constructed (Mumby, 1996). These theories are ideologically committed to the interruption of established disciplinary content through the analysis of subjective experiences of communities, often constrained by overt and hidden power structures (Maguire, 1987). They challenge the privileged position of the researcher in the collection and interpretation of results, and pay close attention to power relations within the research process (Smith, 1994). Feminist researchers challenge the ignoring of women's values and beliefs, patterns of communication, and particular needs and experiences of disenfranchisement in the research process as well as in the larger public sphere (Maguire, 1996, 2001), while postcolonial scholarship situates forms of power such as race, sex, class, and culture within broader geographical, historical, and geopolitical relations (Shome \& Hegde, 2002). Within each of these orientations research is not only about documentation, but rather is a transformative endeavor focused on confronting injustices and disenfranchisement. The goal is to illuminate ways in in which silence and disenfranchisement are perpetuated, where the focus in not just on victimization, but also on celebration of community strength, cultural enablers, and individual and collective agency.

Research that gives voice to those experiencing food insecurity and actively works to facilitate their self-betterment is grounded in "peoples' geography" advocated by scholars such as Harvey (1984) and Mitchell (2008). Harvey defines “peoples' geography" as a rigorous and thoughtful academic scholarship that seeks to understand the roots of disempowerment and the role of knowledge production in the process of liberation. Consistent with other Marxist critiques of knowledge production within the capitalist mode of production, Harvey argues against the supposed ideological neutrality of positivist geography and applied geography, To Harvey,

The world must be depicted, analyzed, and understood [as] the material manifestation of human hopes and fears mediated by powerful and conflicting processes of social 
reproduction. Such a peoples' geography must have a popular base, be threaded into the fabric of daily life with deep taproots into the well-springs of popular consciousness. (1984, p.7)

Adopting a consciously activist viewpoint to critical food scholarship is important in order to transition this research agenda from enumerating the quantity of food-insecure individuals and the exact nature of their problems, to an agenda using the important tools of academic scholarship to advocate for the needs of the hungry within a larger economic system that marginalizes their voices. An example of this type of work includes the community geographer position at Syracuse University in New York state, which works to bridge the divide between critical scholarship and activism, and in particular the Syracuse Hunger Project, which analyzes the structural causes of food insecurity in Syracuse (Mitchell, 2008).

We view voice, participation, and advocacy as important cornerstones of a revised research agenda, and maintain that these epistemological goals can be achieved through a variety of research methodologies, including qualitative, quantitative, and GIS-based research. The fundamental assumption underlying community-based participatory research (CBPR) is that individuals are not objects to be studied, but rather co-researchers in the inception, development, implementation, evaluation, and dissemination of knowledge (Israel, Eng, Schulz, \& Parker, 2005; Minkler \&Wallerstein, 2003). Thus, regardless of the particular research methodology used, what is vital are community dialogues and discussion, the use of co-constructive techniques for data-gathering and analysis, the creation of spaces to listen to the voices of those who are disenfranchised, and the creation of avenues and opportunities for community-driven advocacy (Dutta, 2008; Maguire, 1987). We argue that CBPR should also engage in a conscious process of reflexivity, wherein the power dynamics between the researcher and the researched and the assumptions, biases, and outcomes of the research are interrogated (Kemmis \& McTaggart, 2005).

An example of this is seen in participatory GIS, through which community members are trained in the production and representation of geographic knowledge, and allows them to have a seat at the table in designing, implementing, and analyzing research (Abbot et al., 1998; Chambers, 2006; Curtis \& Oven, 2012; Dunn, 2007; Elwood, 2006). This allows community members to better understand the ways in which hunger operates at multiple spatial scales, and works against the "tyranny of the local" (Allen, 1999) wherein site-specific problems are addressed without engagement with problems faced by similarly situated communities in different locales. Most important, the use of participatory GIS can empower community members to propose interventions that speak to their specific challenges and needs, and allows community members to be involved in the process of research being used in the creation of public policy. Henry-Nickie, Kurban, Green, and Phoenix (2008), for example, describe how universities partnered with community-based organizations in New Orleans to make spatial data available, giving them more voice in the post-Hurricane Katrina rebuilding environment.

Another example of a participatory research methodology that places the subjectivities of disenfranchised people in the foreground is found in the photovoice technique. Photovoice encourages participants to photograph what they consider to be phenomena, people, places, and items significant to their daily existence, and then uses these images to prompt group-based discussions (Wang \& Burris, 1997; Wang \& Redwood-Jones, 2001). Photovoice is rooted in the work of Brazilian philosopher and adult educator Paulo Freire, who argued that participation should facilitate the conscientization and collective action of marginalized people, the goal being to move from a didactic transfer of knowledge to a dialogical construction of knowledge for the purpose of change (Freire, 1970). A novel example of photovoice in the context of hunger is seen in the Voices of Hunger project (Dutta, Anaele, \& Jones, 2013). In this project, , photo exhibits were co-created through interviews, focus groups, and community-wide discussions to enable community members to develop solutions meaningful to their everyday lived experiences. As the scholars note, "The materiality of the imagery co-constructed through community participation 
fosters an empirically grounded space for the sharing of stories from the grassroots that disrupts the portrayal of the poor as lazy in the mainstream logic" (Dutta et al., 2013, p. 5).

\section{Revitalizing Food Insecurity Research}

The existing literature can be strengthened by a research agenda that uses a diverse array of methodologies, but is guided by an epistemological commitment to the voices of people experiencing food insecurity. The mainstream literature on food insecurity has sought to define and operationalize the term, estimate its prevalence, and examine how it interacts with other problems of poverty (Brown, Noonan, \& Nord, 2007; Coleman-Jensen, 2010; De Haen, Klasen, \& Qaim, 2011; Nord, Finberg, \& McLaughlin, 2009). Studies affirm—several times over-the relationship between food insecurity, income, housing, fuel prices, the economy, and the presence of social support networks (De Marco, 2007; Kirkpatrick \& Tarasuk, 2011; Ruel, Garrett, Hawkes, \& Cohen, 2010; Webber \& Rojhani, 2010). We know that food insecurity is tied to socioeconomic problems such as poverty, ill health, lack of school, and as such coordinated efforts are needed to address these problems together. The numbers show that certain groups of people (women, the low income, and racial and ethnic minorities) are more vulnerable to food insecurity and its consequences. However, the structural constraints experienced by food-insecure communities, the social and cultural patterns that shape food values and behaviors at the micro and macro levels, and the manner in which individuals and communities reveal agency in burdensome environments are missing from the larger literature. By partnering with food-shelf clients, for example, to co-design research/action projects that define the structural causes of hunger and put interventions into place to help eradicate obstacles, scholars influenced by critical pedagogies can move beyond documentation to action.

Two areas that could benefit from this new agenda are the food desert and health and obesity literatures. For example, research has been done mapping and defining the term food desert (Hallett IV \& McDermott, 2011; Jiao, Moudon, Ulmer, Hurvitz, \& Drewnowski, 2012; Russell \&
Heidkamp, 2011; Sadler, Gilliland, \& Arku, 2011; Thomas, 2010), as well as working with community members to chronicle how they provision themselves in difficult circumstances (Coveney \& O’Dwyer, 2009; Huang, Rosenberg, Simonovich, \& Belza, 2012; Walker, Butler, Kriska, Keane, Fryer, \& Burke, 2010; Whelan, Wrigley, Warm, \& Cannings, 2002). There is a need, however, for participatory research that works with residents of food deserts to explore how they understand and respond to their local foodscape and that builds the community's capacity to transform the local food environment. A large number of studies have looked at the effects of food insecurity on the health outcomes of overweight and obesity (Brown et al., 2007; Dinour, Bergen, \& Yeh, 2007; Pan, Sherry, Njai, \& Blanck, 2012). We question if the particular issue of obesity is a priority to many of the communities experiencing food insecurity. Using more participatory methods would allow us to uncover a more nuanced reality about how communities prioritize their own risks.

Notably, food scholarship has interrogated systems of agricultural production and the larger capitalist mechanism within which these systems are embedded. The "food bank industrial complex" with its celebration of private volunteerism, promotion of corporate image and responsibility, and distribution of "unsaleable surplus food" from large agro industries has received particular attention (Pelletier, Kraak, McCullum, \& Uusitalo, 2000; Poppendieck, 1999; Rocha, 2007; Tarasuk \& Eakin, 2005). Other studies have looked at the various ways in which people cope with the problem of food insecurity focusing on government and community food-assistance programs (Berner, Paynter, \& Anderson, 2009; Whitley, 2013), but the question of how scholarship can play a role in mobilizing communities for self-betterment and self-determination remains unanswered.

Scholars have also investigated the concept of food justice and outlined inequities in the current systems of food production, distribution, and consumption (Gottlieb \& Fisher, 1996; Gottlieb \& Joshi, 2010; Winne, 2005, 2009). A recently emerging trend grounded in the work of activists has examined the radical potential as well as problems inherent in "alternative" solutions to the problem 
of food insecurity, such as urban gardening, mobile markets, and novel ways in which food banks can operate (Allen, 1999; Johnston \& Baker, 2005; Phoenix \& Walter, 2009; Slocum, 2006). We believe that this body of work can be strengthened by incorporating the voices of people experiencing food insecurity in the design and implementation of research projects, such that solutions do not continue to favor the interests of White, Western, and middle-class Americans. In sum, there is a need for food scholarship that more directly represents the lives of those experiencing food insecurity in order to understand how communities can mobilize themselves for food security and empowerment.

Food insecurity is directly linked to larger societal problems such as economic inequality and political marginalization. However, these systemic issues have none of the visceral connections to home, health, and family that food insecurity does; anti-hunger campaigns can mobilize millions of apolitical people into action in a way that other issues cannot. While we applaud these actions it is incumbent upon scholars to frame food insecurity using a lens that accurately reflects the lived experiences of those experiencing hunger, and the most effective potential solutions. To do so, the research agenda of food scholars must be repositioned to focus squarely on forming partnerships with communities experiencing food insecurity and using their voices to guide activism.

\section{References}

Abbot, J., Chambers, R., Dunn, C., Harris, T., de Merode, E., Porter, G.,...Weiner, D. (1998, October). Participatory GIS: Opportunity or oxymoron? PLA Notes, 33, 27-34.

Allen, P. (1999). Reweaving the food security safety net: Mediating entitlement and entrepreneurship. Agriculture and Human Values, 16(2), 117-129. http://dx.doi.org/10.1023/A:1007593210496

Anderson, M. D. (2008). Rights-based food systems and the goals of food systems reform. Agriculture and Human Values, 25(4), 593-608. http://dx.doi.org/10.1007/s10460-008-9151-z

Berner, M., Paynter, S., \& Anderson, E. (2009, April). When the even the "dollar value meal" costs too much: Food insecurity and long term dependence on food pantry assistance. Paper presented at the annual conference of the Midwest Political Science Association.

Brown, B., Noonan, C., \& Nord, M. (2007). Prevalence of food insecurity and health-associated outcomes and food characteristics of Northern Plains Indian households. Journal of Hunger \& Environmental Nutrition, 1(4), 37-53. http://dx.doi.org/10.1300/J477v01n04 04

Chambers, R. (2006). Participatory mapping and geographic information systems: Whose map? Who is empowered and who disempowered? Who gains and who loses? Electronic Journal of Information Systems in Developing Countries, 25(2), 1-11. Available at http://www.ejisdc.org

Chilton, M., \& Rose, D. (2009). A rights-based approach to food insecurity in the United States. American Journal of Public Health, 99(7), 1203-1211. http://dx.doi.org/10.2105/AJPH.2007.130229

Coleman-Jensen, A. J. (2010). U.S. Food insecurity status: Toward a refined definition. Social Indicators Research, 95(2), 215-230. http://dx.doi.org/10.1007/s11205-009-9455-4

Coveney, J., \& O’Dwyer, L. A. (2009). Effects of mobility and location on food access. Health \& Place, 15(1), 45-55. http://dx.doi.org/10.1016/j.health place.2008.01.010

Curtis, S. E., \& Oven, K. J. (2012). Geographies of health and climate change. Progress in Human Geography, 36(5), 654-666. http://dx.doi.org/10.1177/0309132511423350

De Haen, H., Klasen, S., \& Qaim, M. (2011). What do we really know? Metrics for food insecurity and undernutrition. Food Policy, 36(6), 760-769. http://dx.doi.org/10.1016/j.foodpol.2011.08.003

De Marco, M. M. (2007). The relationship between income and food insecurity: The role of social support in rural and urban Oregonians (Doctoral dissertation). Oregon State University, Corvallis, Oregon. Retrieved from http://hdl.handle.net/1957/6239

DeLind, L. B. (1994). Celebrating hunger in Michigan: A critique of an emergency food program and an alternative for the future. Agriculture and Human Values, 11(4), 58-68. http://dx.doi.org/10.1007/BF01530417 
Dinour, L. M., Bergen, D., \& Yeh, M.-C. (2007). The food insecurity-obesity paradox: A review of the literature and the role food stamps may play. Journal of the Academy of Nutrition and Dietetics, 107(11), 1952-1961. http://dx.doi.org/10.1016/j.jada.2007.08.006

Dunn, C. E. (2007). Participatory GIS-A people's GIS? Progress in Human Geography, 31(5), 616-637. http://dx.doi.org/10.1177/0309132507081493

Dutta, M. J. (2008). Communicating health: A culture-centered approach. Cambridge, UK: Polity Press.

Dutta, M. J., Anaele, A., \& Jones, C. (2013). Voices of hunger: Addressing health disparities through the culture-centered approach. Journal of Communication, 63(1), 159-180. http://dx.doi.org/10.1111/jcom.12009

Elwood, S. (2006). Critical issues in participatory GIS: Deconstructions, reconstructions, and new research directions. Transactions in GIS, 10(5), 693-708. http://dx.doi.org/10.1111/j.14679671.2006.01023.x

Freire, P. (1970). Pedagogy of the oppressed. New York: Seabury Press.

Gottlieb, R., \& Fisher, A. (1996). Community food security and environmental justice: Searching for a common discourse. Agriculture and Human Values, 13(3), 23-32. http://dx.doi.org/10.1007/BF01538224

Gottlieb, R., \& Joshi, A. (2010). Food Justice. Cambridge, Massachusetts: MIT Press.

Hallett IV, L. F., \& McDermott, D. (2011). Quantifying the extent and cost of food deserts in Lawrence, Kansas, USA. Applied Geography, 31(4), 1210-1215. http://dx.doi.org/10.1016/j.apgeog.2010.09.006

Harvey, D. (1984). On the history and present condition of geography: An historical materialist manifesto.

The Professional Geographer, 36(1), 1-11. http://dx.doi.org/10.1111/j.00330124.1984.00001.x

Henry-Nickie, M., Kurban, H., Green, R., \& Phoenix, J. (2008). Leveling the playing field: Enabling community-based organizations to utilize geographic information systems for effective advocacy. URIS A, 20(2), 33-41. Retrieved from http://www.urisa.org/urisajournal

Huang, D. L., Rosenberg, D. E., Simonovich, S. D., \& Belza, B. (2012). Food access patterns and barriers among midlife and older adults with mobility disabilities. Journal of Aging Research, 2012, 1-8, article ID 231489.

http://dx.doi.org/10.1155/2012/231489

Israel, B., Eng, E., Schulz, A., \& Parker, E. (2005). Methods in community-based participatory research for health. San Francisco, CA: Josey-Bass.

Jiao, J., Moudon, A. V., Ulmer, J., Hurvitz, P. M., \& Drewnowski, A. (2012). How to identify food deserts: Measuring physical and economic access to supermarkets in King County, Washington. American Journal of Public Health, 102(10), e32-e39. http://dx.doi.org/10.2105/ajph.2012.300675

Johnston, J., \& Baker, L. (2005). Eating outside the box: FoodShare's Good Food Box and the challenge of scale. Agriculture and Human V alues, 22(3), 313-325. http://dx.doi.org/10.1007/s10460-005-6048-y

Kemmis, S., \& Mc'Taggart, R. (2005). Participatory action research: Communicative action and the public sphere. In N. K. Denzin \& Y. S. Lincoln (Eds.), The SAGE handbook of qualitative research (pp. 559-604). Thousand Oaks, California: Sage Publications.

Kincheloe, J. L., \& McLaren, P. (2000). Rethinking critical theory and qualitative research. In N. K. Denzin \& Y. S. Lincoln (Eds.), Handbook of qualitative research (2nd Ed.) (pp. 279-313). Thousand Oaks, California: Sage Publications.

Kirkpatrick, S. I., \& Tarasuk, V. (2011). Housing circumstances are associated with household food access among low-income urban families. Journal of Urban Health, 88, 284-296. http://dx.doi.org/10.1007/s11524-010-9535-4

Maguire, P. (1987). Doing participatory research: A feminist approach. Amherst, Massachusetts: University of Massachusetts.

Maguire, P. (1996). Considering more feminist participatory research: What's congruency got to do with it? Qualitative Inquiry, 2(1), 106-118. http://dx.doi.org/10.1177/107780049600200115

Maguire, P. (2001). Uneven ground: Feminisms and action research. In P. Reason \& H. Bradbury-Huan (Eds.), Handbook of Action Reseach: Participative Inquiry and Practice (pp. 59-69). London: Sage Publications.

Mitchell, D. (2008). Confessions of a desk-bound radical. Antipode, 40(3), 448-454. http://dx.doi.org/ 10.1111/j.1467-8330.2008.00613.x 
Mumby, D. K. (1996). Feminism, postmodernism and organizational communication studies: A critical reading. Management Communication Quarterly, 9(3), 259-295. http://dx.doi.org/10.1177/0893318996009003001

Nord, M., Finberg, M., \& McLaughlin, J. (2009). What should the government mean by hunger? Journal of Hunger \& Environmental Nutrition, 4(1), 20-47. http://dx.doi.org/10.1080/19320240802706825

Pan, L., Sherry, B., Njai, R., \& Blanck, H. M. (2012). Food insecurity is associated with obesity among US adults in 12 states. Journal of the Academy of Nutrition and Dietetics, 112(9), 1403-1409. http://dx.doi.org/10.1016/j.jand.2012.06.011

Pelletier, D. L., Kraak, V., McCullum, C., \& Uusitalo, U. (2000). Values, public policy, and community food security. Agriculture and Human Values, 17(1), 75-93. http://dx.doi.org/10.1023/A:1007668425322

Phoenix, L., \& Walter, L. (Eds.). (2009). Critical food issues: Problems and state-of-the-art solutions worldwide. Santa Barbara, California: Praeger.

Poppendieck, J. (1999). Sweet charity?: Emergency food and the end of entitlement. New York: Penguin Putnam Books.

Retzinger, J. (2012). Empty bellies/empty calories: Representing hunger and obesity. In J. J.. Frye \& M. S. Bruner (Eds.), The rhetoric of food: Discourse, materiality, and power (pp. 22-41). New York: Routledge

Rocha, C. (2007). Food insecurity as market failure: A contribution from economics. Journal of Hunger \& Environmental Nutrition, 1(4), 5-22. http://dx.doi.org/10.1300/J477v01n04 02

Ruel, M. T., Garrett, J. L., Hawkes, C., \& Cohen, M. J. (2010). The food, fuel, and financial crises affect the urban and rural poor disproportionately: A review of the evidence. Journal of Nutrition, 140(1), 170S176S. http://dx.doi.org/10.3945/in.109.110791

Russell, S. E., \& Heidkamp, C. P. (2011). 'Food desertification': The loss of a major supermarket in New Haven, Connecticut. Applied Geography, 31(4), 1197-1209. http://dx.doi.org/10.1016/j.apgeog.2011.01.010

Sadler, R., Gilliland, J., \& Arku, G. (2011). An application of the edge effect in measuring accessibility to multiple food retailer types in Southwestern Ontario, Canada. International Journal of Health Geographics, 10(1), 34. http://dx.doi.org/10.1186/1476-072X-10-34

Sen, A. (1983). Poverty and famines: An essay on entitlement and deprivation. New York: Oxford University Press.

Shome, R., \& Hegde, R. S. (2002). Postcolonial approaches to communication: Charting the terrain, engaging the intersections. Communication Theory, 12(3), 249-270. http://dx.doi.org/10.1111/j.14682885.2002.tb00269.x

Slocum, R. (2006). Anti-racist practice and the work of community food organizations. Antipode, 38(2), 327-349. http://dx.doi.org/10.1111/j.14678330.2006.00582.x

Smith, N. (1994). Geography, empire and social theory. Progress in Human Geography, 18(4), 491-500. http://dx.doi.org/10.1177/030913259401800404

Tarasuk, V., \& Eakin, J. M. (2005). Food assistance through "surplus" food: Insights from an ethnographic study of food bank work. Agriculture and Human V alues, 22(2), 177-186. http://dx.doi.org/10.1007/s10460-004-8277-x

Thomas, B. F. (2010). Food deserts and the sociology of space: Distance to food retailers and food insecurity in an urban American neighborhood. World Academy of Science, Engineering and Technology, 67, 19-28.

Walker, R. E., Butler, J., Kriska, A., Keane, C., Fryer, C. S., \& Burke, J. G. (2010). How does food security impact residents of a food desert and a food oasis? Journal of Hunger \& Environmental Nutrition, 5(4), 454-470. http://dx.doi.org/10.1080/19320248.2010.530549

Wang, C. C., \& Burris, M. (1997). Photovoice: Concept, methodology, and use for participatory needs assessment. Health Education \& Behavior, 24(3), 369387.

http://dx.doi.org/10.1177/109019819702400309

Wang, C. C., \& Redwood-Jones, Y. A. (2001). Photovoice ethics: Perspectives from Flint photovoice. Health Education \& Behavior, 28(5), 560572 . http://dx.doi.org/10.1177/109019810102800504

Webber, C. B., \& Rojhani, A. (2010). Food or fuel: Rising gasoline prices and food access among WIC families in non-metropolitan southwest Michigan. Journal of Hunger \& Environmental Nutrition, 5(4), 484-497. http://dx.doi.org/10.1080/19320248.2010.527279 
Whelan, A., Wrigley, N., Warm, D., \& Cannings, E. (2002). Life in a "food desert." Urban Studies, 39(11), 2083-2100.

http://dx.doi.org/10.1080/0042098022000011371

Whitley, S. (2013). Changing times in rural America:

Food assistance and food insecurity in food deserts.

Journal of Family Social Work, 16(1), 36-52.

http://dx.doi.org/10.1080/10522158.2012.736080
Winne, M. (2005). Waste not, want not? Agriculture and Human Values, 22(2), 203-205 http://dx.doi.org/10.1007/s10460-004-8279-8

Winne, M. (2009). Closing the food gap: Resetting the table in the land of plenty. Boston: Beacon Press. 